\title{
A stakeholder theory approach to creating value in higher education institutions
}

Stakeholder theory approach

\author{
Taiguara de Freitas Langrafe and Simone Ruchdi Barakat \\ Álvares Penteado School of Commerce Foundation (FECAP), \\ São Paulo, Brazil \\ Fabricio Stocker
}

School of Economics, Business and Accounting, University of São Paulo, Brazil and School of Management, Erasmus University Rotterdam, Rotterdam, The Netherlands, and

\section{Joao Maurício Gama Boaventura}

School of Economics, Business and Accounting, University of São Paulo, Sao Paulo, Brazil

\begin{abstract}
Purpose - This paper aims to empirically verify whether the development of improved relationships between higher education institutions (HEIs) and their stakeholders based on the principles of stakeholder theory creates more value.

Design/methodology/approach - The methods involve a quantitative approach, with the data collection being carried out through a survey of 88 heads of HEIs in Brazil. The paper uses the Spearman's correlation coefficient to analyze the data and test the hypotheses.

Findings - The findings reinforce the arguments found in the stakeholder theory literature, in which relationships are based on the following principles: knowledge and information sharing, mutual trust, involvement in the decision-makin g process and alignment of stakeholders' interests in the strategic planning process, all of which create more value for organizations.

Practical implications - This study seeks to improve the knowledge of stakeholder theory in relation to HEIs. It identifies the stakeholder relationships that create the most value and have the potential to generate a sustainable competitive advantage. The results can help managers to improve their relationships with stakeholders and may encourage the implementation of practices and policies that consider stakeholders' influence on the strategic direction of HEIs.

Social implications - The studies present a social contribution by evidencing the importance of the development of best practices, processes and strategies in the management of educational institutions, which are important actors in the development of society.

Originality/value - The originality of this paper is that it empirically tests the principles of stakeholder theory and their relationships with value creation for organizations in the higher education context. Whilst

(C) Taiguara de Freitas Langrafe, Simone R. Barakat, Fabricio Stocker and Joao Maurício Gama Boaventura. Published by Emerald Publishing Limited. This article is published under the Creative Commons Attribution (CC BY 4.0) licence. Anyone may reproduce, distribute, translate and create derivative works of this article (for both commercial and non-commercial purposes), subject to full attribution to the original publication and authors. The full terms of this licence may be seen at: http://creativecommons.org/licences/by/4.0/legalcode
\end{abstract}

Received 5 March 2020 Revised 5 May 2020 15 May 2020 Accepted 19 May 2020 
BL 33,4

stakeholder theory has been explored in multiples contexts, there is a lack of studies addressing stakeholder management in HEIs.

Keywords Managing for stakeholders, Value creation, Stakeholder relationships, higher education

Paper type Research paper

\section{Introduction}

Stakeholder theory emerged in the 1980s as a response to the growing dynamism and complexity of the environment in which organizations operate. In this approach, all the individuals or groups that have a stake in the organization are considered in the strategic management and the organization is managed with the purpose of creating value for customers, suppliers, owners, employees and local communities (Freeman et al., 2020).

Stakeholder theory has been gaining increased acceptance and relevance in strategic management research and business practices, however, its nuances still need to be better studied at a broader scope and in less explored contexts such as higher education institutions (HEIs). These organizations play a key role in society, not only because of their educational purpose but also as they are responsible for scientific investigation and the transfer of knowledge to develop the broader community (Bilodeau et al., 2014; Ferrero-Ferrero et al., 2018). The existence of an HEI can be justified via its stakeholder relationships. Many internal and external stakeholders can influence higher education objectives such as the quality of teaching and development of partnership research projects (Kettunen, 2015). Thus, to improve relationships with stakeholders it is necessary to devise comprehensive strategies that ensure collaboration and engagement with stakeholders (Stocker et al., 2020).

HEIs are now operating as quasi-commercial organizations and their success depends on their ability to adopt efficient management approaches (Cho, 2017). These institutions have a particularly complex set of stakeholders and neglecting stakeholder relationships may lead to limited success and insufficient value creation (Kettunen, 2015). Thus, mapping these stakeholders and considering their interests and demands is relevant for the broader society and urgent for the survival of such institutions. Given this context, the purpose of this study is to empirically verify whether the development of improved relationships between HEIs and their stakeholders based on the principles of stakeholder theory creates more value. This investigation is important, as stakeholder theory advocates that managing for relevant stakeholders is a means by which organizations can develop valuable relationships and gain competitive advantage.

We test whether the following principles of stakeholder theory create more value for HEIs:

- The active involvement of stakeholder groups in the decision-making process;

- The exchange of information about stakeholders' demands and preferences;

- The development of a relationship of mutual trust between stakeholders and the organization; and

- The inclusion of stakeholders in the strategic planning process.

We test these hypotheses by assessing the perceptions of top managers of HEIs in Brazil regarding the dynamics of the relationships between the organizations and their stakeholders and the value that these relationships provide. Such an empirical analysis is relevant, as most of the previous stakeholder literature focuses on the organizational level and not the individual decision-maker level (Pirson et al., 2017), even though stakeholder theory emerged as a framework whose central figure is the manager (Freeman et al., 2010). 
This paper presents at least three different contributions. Theoretically, our main contribution is to propose that the implementation of the principles of stakeholder management creates more value for organizations in the context of HEIs, thus advancing strategic management studies in this field. The second contribution lies in providing practitioners and managers of educational institutions insights for the improvement of relationships and involvement with their stakeholders. Finally, the work presents a social contribution by evidencing the importance of the development of best practices, processes and strategies in the management of educational institutions, which are important actors in the development of society.

\section{Theoretical background}

The seminal work of Freeman (1984) is considered to be the initial and most important landmark of stakeholder theory literature. The author argues that there is a need for a paradigm change in the management of organizations in alignment with new social demands and trends. In order for an organization to succeed in this new context, the managers have to simultaneously satisfy owners, employees and their unions, suppliers and customers. Managing relationships with stakeholders have also been increasingly seen as a strategic means of approaching organizational actions geared toward social issues (Freeman et al., 2020).

In its evolution, stakeholder theory has pointed out different questions for the strategic management of organizations such as how to identify and prioritize stakeholders, how to understand their interests and demands, how to balance the relationships among various stakeholders and how to engage stakeholders in organizational activities (Freeman et al., 2010; Harrison et al., 2010; Sulkowski et al., 2018). According to Stoner and Freeman (1999), stakeholders can be classified into the following two categories: internal and external. The internal stakeholders are those who act within the organization such as owners and employees. The external stakeholders are those that interact directly with the organization such as customers and suppliers.

\section{Managing for stakeholders and value creation}

More recently, stakeholder theorists have focused their attention on the mechanisms of creating and distributing value to stakeholders (Freeman et al., 2010; Harrison et al., 2010; Harrison and Bosse, 2013; Garcia-Castro and Aguilera, 2015; Tantalo and Priem, 2016; Boaventura et al., 2020). Instead of focusing on analyzing, which stakeholders are most important and prioritizing their demands, improving relationships that create more value has become the focus. Most of this body of studies, though, is conceptual, indicating that this discussion is at the frontier of knowledge on stakeholder theory (Freeman et al., 2020).

Value is an important concept in the strategy field (Garcia-Castro and Aguilera, 2015). For stakeholder theory, value creation is embedded in the relationship between the organization and its stakeholders (Bosse and Coughlan, 2016). By emphasizing different forms of value creation, Harrison and Wicks (2013) advance the traditional approach of assessing value creation as limited to the economic dimension and propose that measures of organizational performance should consider the perspective of multiple stakeholders. The authors consider that value is "anything that has the potential to be of worth to stakeholders" (p. 100-101), including both tangible and intangible factors that are important to stakeholders. Value can refer, for instance, to community service programs, employee participation in the decision-making process, better payment conditions for suppliers, lower prices for customers, etc (Harrison et al., 2010). 
BL 33,4

From this perspective, managers should promote value creation and distribute that value to stakeholders through the effective management of relationships (Harrison and Bosse, 2013). The management of relationships is important for understanding what is considered valuable for each stakeholder group, and thus, for the appropriate allocation of resources to meet their demands. Freeman et al. (2020) point out that managing stakeholders deal with broad and complex aspects and should include processes and procedures that promote justice in the distribution of resources.

\section{Managing for stakeholders in higher education institutions}

High competitiveness requires HEIs to develop other types of capabilities that were not previously required such as management of relationships with their students, preparation of students for the job market, development of their brands and monitoring of performance (Mainardes et al., 2010). Added to this, it is expected that HEIs promote teaching and research that are relevant to the construction of new knowledge and the development of new forms of production (Jongbloed et al., 2008).

New perspectives on education in the most recent decades such as greater access to a greater number of people and rapid introduction of technology have pushed for an increased opening of HEIs activities to society and to all those around them. In the same sense, the new requirements of business and the competitive logic of the market have intensified the need for HEIs to know and meet the needs of their stakeholders. The identification of different stakeholders and the ability to meet their needs has become an essential requirement for organizational performance also in the education context (Ferrero-Ferrero et al., 2018). While, in a broad sense, stakeholder theory consider the shareholders, employees, community, government, customers and suppliers as the generic stakeholder's groups (Freeman, 1984), the specific stakeholders of HEIs are the maintainer of the institution, technical-administrative body, faculty, labor market, alumni, community, ministry of education (MEC) and students (INEP, 2018; Mainardes et al., 2010).

Regarding the classification of stakeholders into internal and external groups, there are also particular features of HEIs. On the one hand, the technical-administrative body carries a close relationship between their professional activities and the institution, but they have relatively low power in fulfilling the different purposes of the institution. On the other hand, faculty have very high power in carrying out these missions, but they have more disperse relationships with the institution and the other professional activities they carry out such as research groups, projects in partnership with other institutions and financing entities (Lourenço and Mano, 2017).

Students also appear as a particular case, being able to assume two different roles. On the one hand, they are customers of HEIs, as external stakeholders, not only because they are those who consume the educational services but also because they are those who spend financial resources to acquire this same service. On the other hand, the teaching activity is characterized by having a very long period of consummation of the student, where they are co-producer of the activity, not only participating actively in the process but also generating added value due to this level of participation, thus placing them in an internal stakeholder role (Lourenço and Mano, 2017).

\section{Hypotheses development}

An underlying premise of stakeholder theory is that stakeholders will cooperate more with the organization the more they perceive their interests being served. In other words, stakeholders seek to relate to the organization in accordance with the principles of fairness, in which the contribution offered is proportional to the value received (Phillips, 1997; 
Boaventura et al., 2020;). According to this logic, we propose that relationships with stakeholders characterized by the principles of stakeholder theory create more value for organizations. More specifically, we propose that relationships characterized by:

- Stakeholder participation in the decision-making process;

Stakeholder theory approach

- The exchange of information;

- Mutual trust; and

- Inclusion in the strategic planning process is associated with greater value creation for organizations.

Below, we will develop these arguments further.

Stakeholder groups can contribute with their own knowledge, skills and experience to increase the exchange of ideas with organizations and reduce the likelihood of dissatisfaction among one or more groups (Esterhuyse, 2019; Ngah and Wong, 2020). Conditions, as well as stakeholders' demands, change over time, making it important for organizations to assess the ideas and concerns of stakeholders through interaction and dialogue. A greater exchange of information with stakeholders allows for a better understanding of their interests and preferences (Li and Nguyen, 2017; Kolding et al., 2018).

Knowledge about stakeholder preferences can potentially increase the efficiency with which a company allocates its resources (Harrison et al., 2010). To analyze what each stakeholder recognizes as valuable, we can use the concept of the utility function. The utility function of a stakeholder group shows its preferences for different combinations of tangible and intangible outcomes. These preferences are determined by its perception of how interactions with the company influence the utility it receives (Harrison and Wicks, 2013).

Stakeholders are unique sources of information and different groups of stakeholders can provide the company with a variety of information that can be combined to create value (Garcia-Castro and Aguilera, 2015; Parnell et al., 2018; Esterhuyse, 2019). The sharing of information with stakeholder groups can lead to a more efficient allocation of resources and an increased ability to cope with unexpected changes in the context and in the preferences of those stakeholders. This logic suggests that as follows:

H1. The exchange of information about the demands and preferences of stakeholder groups creates more value for the organization.

Decisions within organizations result from actions taken by the decision-makers. Such individuals have their own objectives, which may be different from the objectives of the organization and other stakeholders (Child et al., 2010). The goals and interests of managers affect the entire decision-making process in organizations. The influence of power and political behavior in decision-making processes within an organization can lead managers to make decisions based on incomplete or even distorted information, creating organizational façades with no regard for the reality and demands of important stakeholders (Stone et al., 2019; Bridoux and Vishwanathan, 2020).

The multidimensional nature of decision-making requires the involvement of different perspectives and not only that of managers. Each stakeholder has a different perception of decision problems according to their own values, concerns and objectives, and thus, engaging other parties in this process is important (Pirson et al., 2017). One way to equalize the risks of the decision-making process is to involve stakeholders in the process by sharing the responsibilities and gains.

It is also possible to say that participation in decision-making is related to stakeholder prioritization. The greater the importance, power, influence, and other attributes that 
BL 33,4

characterize a stakeholder and its prioritization, the greater the likelihood of the organization engaging it in decision-making (Stone et al., 2017). This argument is already discussed in the literature on stakeholder engagement such as by Friedman and Miles (2006) and Stocker et al. (2020), who propose levels of engagement, where the higher the level of engagement, the greater the participation in decision-making.

Stakeholder involvement can be obtained by their participation in decision-making processes, based on several studies, MacDonald et al. (2019) emphasize that stakeholder participation in decision-making has been recommended to bring competitive advantages to organizations. According to this logic, we propose that as follows:

H2. The active participation of stakeholder groups in the decision-making process creates more value for the organization.

Stakeholder theorists claim that managers should create and maintain mutually trusting and cooperative relationships with stakeholders (Jones et al., 2018; Bosse and Coughlan, 2016). Trust is a fundamental aspect of the moral treatment of stakeholders. Hosmer (1995, p. 399) defines trust as "the expectation by one person, group or firm of ethically justifiable behavior on the part of the other person, group or firm in a joint endeavor or economic exchange." Stakeholders have to trust the organization to return benefits derived from their contributions or stakes (Crane, 2020).

Such behavior would increase the potential for value creation, given that people tend to treat the other party within an exchange fairly when they realize that this party is behaving fairly toward them and toward other people as well (Bosse and Coughlan, 2016). The perception of organizational justice may lead stakeholders to dedicate more effort to their relationships with the company. For example, it can lead employees to work harder and share valuable information with the organization; consumers to increase their exchanges, demands and loyalty; suppliers to offer better deals; and communities to support expansion projects (Harrison and Bosse, 2013).

As argued by Pirson et al. (2017), scholars are beginning to better understand stakeholders' trust in companies and how stakeholders will be more willing to contribute to value creation if they trust and perceive an organization as fair. Relationships based on the principles of justice and fairness can enhance opportunities for partnership and joint development and lead to greater stakeholder engagement. According to this logic, we propose that as follows:

H3. A relationship of mutual trust with stakeholder groups creates more value for the organization.

Stakeholder theory argues that the development of reciprocal and strategic relationships with stakeholders creates improved value (Harrison and Bosse, 2013). Although the normative perspective of stakeholder theory considers all stakeholders to have interests with intrinsic values regardless of their impact on the organization's performance, the strategic perspective of stakeholder management focuses on the relationships that are relevant for improving performance (Freeman et al., 2020). Thus, the strategic view of stakeholder theory suggests that organizations can create more value by distributing it to stakeholders that are relevant for organizational goals (Boaventura et al., 2020). Stakeholder theory is not only seen as an ethical theory that is disconnected from management but also rather as one that is related to corporate performance.

Freeman et al. (2020) explain that a stakeholder framework is first and foremost a management approach, which focuses on concrete business issues, addressing how 
stakeholder management can lead to better organizational outcomes by incorporating stakeholder interests into business strategies. In addition, to thinking about what actions companies should and should not take to meet moral standards, attention is given to the relationships that companies should promote with their strategic stakeholders (Boaventura et al., 2020). According to this logic, we propose that as follows:

H4. Considering stakeholder groups as relevant in the process of organizational strategic planning creates more value for the organization.

Stakeholder theory approach

\section{Methods}

Data collection

According to the National Institute of Educational Studies (INEP), an autarchy associated with the MEC of the Federal Government of Brazil, there were 2,391 HEIs in Brazil in 2013 301 public HEIs and 2,090 private ones, according to the last report published in 2013, a period that preceded the data collection carried out in 2014. Currently, the number of HEIs is 2,448, 296 of which are public and 2,152 private HEIs (INEP, 2017). The concentration of private institutions is due to public policies in the past decades that allowed greater access to private capital to higher education.

The primary data were collected through a survey of the heads of the HEIs in Brazil. The survey contained questions regarding the profile of the respondents, the profile of the institutions and the respondents' perceptions regarding the relationships with groups of stakeholders (items shown in Table 2). The survey was sent to the official email addresses of the main managers of all the 2,391 HEIs registered and available in the online system of the MEC and included in the census of higher education in Brazil. The collection gathered 178 individual answers, which represents an 7,44\% response rate. Of these, 88 were considered valid as they were completed in full.

\section{Data collection instrument}

The first step in designing the data collection instrument was to identify the relevant stakeholders. To list them, this study considered the report that evaluates HEIs in Brazil developed by INEP (2018), which was then compared with the generic primary stakeholder groups listed in the stakeholder literature. Table 1 shows the generic list of stakeholders commonly used in the literature, the corresponding stakeholders in the HEI context provided by INEP and their description.

To identify the relevant stakeholders of the HEIs for the empirical investigation, the stakeholder list provided by INEP was then validated by experts. We consulted 10 experts five of which were researchers with broad experience in the stakeholder literature and five of which were managers of HEIs. In the original list provided by INEP, the stakeholder group suppliers were not considered. After consultation with the experts, this group was included.

The second step in designing the instrument was to define the items to measure the principles of stakeholder theory and value creation. These items were developed according to the literature and were then validated by the experts. We used a 10-point Likert scale. Table 2 shows the items used for measuring each construct and its corresponding theoretical foundation.

\section{Data analysis}

The data analysis was carried out in three steps. The first step consisted of the descriptive analysis of the answers related to the characterization of the respondents' profiles and the characterization of the HEIs' profiles. 


$\begin{array}{ll}\begin{array}{l}\text { Generic stakeholder } \\ \text { group }\end{array} & \begin{array}{l}\text { Corresponding stakeholder } \\ \text { group in the HEIs }\end{array}\end{array}$

Shareholders Maintainer of the institution

$304 \quad$ Employees

Community

Table 1.

Stakeholders identified in the literature and in the HEI context

$\begin{array}{ll}\text { Government } & \text { Community } \\ \text { Customers } & \text { MEC } \\ \text { Students } \\ \text { Suppliers } & \text { Suppliers }\end{array}$

Labor market
Description

The one who guarantees the functioning of the institution, making available financial resources or not

Technical-administrative body

Faculty

Alumni

All administrative and technical employees of the HEI

All professors at the HEI

Employers and contractors of students

All individuals who were students of the

HEI

Community living around the HEI

Regulatory body for the sector

Students or potential students enrolled in the institution

Procurement of resources for the activities of the HEI and outsourced services

\section{Table 2.}

Items used for measuring the constructs and corresponding theoretical foundation

\begin{tabular}{|c|c|c|}
\hline Construct & Item & Theoretical foundation \\
\hline $\begin{array}{l}\text { Exchange of } \\
\text { information }(H 1)\end{array}$ & $\begin{array}{l}\text { The exchange of information with this } \\
\text { stakeholder allows for an } \\
\text { understanding of their demands and } \\
\text { desires }\end{array}$ & $\begin{array}{l}\text { Garcia-Castro and Aguilera } \\
\text { (2015), Harrison and Wicks } \\
\text { (2013); Harrison et al. (2010) }\end{array}$ \\
\hline $\begin{array}{l}\text { Participation in the } \\
\text { decision-making } \\
\text { process }(H 2)\end{array}$ & $\begin{array}{l}\text { This stakeholder actively participates, } \\
\text { through meetings or representations on } \\
\text { councils, in the decision-making } \\
\text { processes of the HEI }\end{array}$ & $\begin{array}{l}\text { Child et al. (2010); Chakhar } \\
\text { and Saad (2014); MacDonald } \\
\text { et al. (2019) }\end{array}$ \\
\hline $\begin{array}{l}\text { Relationship of } \\
\text { mutual trust (H3) }\end{array}$ & $\begin{array}{l}\text { There is a relationship based on mutual } \\
\text { trust between the HEI and this } \\
\text { stakeholder }\end{array}$ & $\begin{array}{l}\text { Greenwood and Van Buren } \\
\text { (2010); Harrison and Bosse } \\
\text { (2013); Schneider and Sachs } \\
\text { (2017) }\end{array}$ \\
\hline $\begin{array}{l}\text { Relevance in the } \\
\text { strategic planning } \\
\text { process (H4) }\end{array}$ & $\begin{array}{l}\text { This stakeholder is considered to be } \\
\text { relevant in the HEI's strategic planning } \\
\text { process }\end{array}$ & $\begin{array}{l}\text { Freeman et al. (2010), } \\
\text { Harrison et al. (2010) }\end{array}$ \\
\hline $\begin{array}{l}\text { Value creation ( } H 1 \text {, } \\
H 2, H 3 \text { and } H 4)\end{array}$ & $\begin{array}{l}\text { The relationship with this stakeholder } \\
\text { generates substantial value for the HEI } \\
\text { The relationship with this stakeholder } \\
\text { generates substantial value for the } \\
\text { stakeholder }\end{array}$ & $\begin{array}{l}\text { Bosse } \text { et al. (2009); Freeman } \\
\text { et al. (2010) }\end{array}$ \\
\hline
\end{tabular}

The second step involved the analysis of reciprocity in the relationships between the organization and its stakeholders. This analysis was conducted through the $t$-test, in which it was possible to verify differences in the means for each group of stakeholders regarding the respondents' perceptions of the value that each group generates for the institution and the value that is generated for each stakeholder group.

The third step was the analysis of the correlations of the constructs using the Spearman's correlation coefficient obtained in the SPSS ${ }^{\circledR}$ software to test the hypotheses. Spearman's correlation coefficient measures the strength of a linear correlation between two quantitative 
variables. Spearman's correlation is appropriate when the data are interval, ratio or ordinal. Also, there is no normality requirement, and hence, it is a non-parametric test. Its values range between -1.0 and 1.0, which reflects the intensity of a linear relationship between two data sets (Field, 2013).

\section{Results}

\section{Characterization of the respondents}

The sample consisted of 88 respondents, whose average age was 48.2 years old. The minimum value was 26 and the maximum was 75 . With regard to gender, there was a predominance of men as the main managers of the HEIs. There were 67 men, 20 women and one who did not declare their gender. The period in which the respondents have been working as heads of the HEIs varies from one year to 40 years. The mean was 10.67 years. The period that they have been working in their current HEI varies from less than one to 20 years and the average is 6.56 years. This shows a stable situation, in which the cycles of the heads of the HEIs in the sample are reasonably high.

The majority of the sample (83\%) reported having experience in general administration. This situation is as expected, as the activities of the head of an HEI are of a general nature. The second most cited activity was consultancy (30.7\%), followed by public management $(27.3 \%)$. Also, $20.5 \%$ of the respondents reported having a share in the ownership of the HEI or carrying out the role of the maintainer of the institution.

\section{Characterization of the higher education institutions}

The majority of the HEIs in the sample are non-profit, of which $18(20.5 \%)$ are public and 37 $(42 \%)$ are private, including foundations and philanthropic institutes. In Brazil, $14.4 \%$ of HEIs are public and $86.6 \%$ are private, as shown in Table 3.

The average number of students in undergraduate programs was 6,659. The maximum value was 60,000 and the minimum was 98 students. The number of students in undergraduate programs can be considered as a proxy to assess the size of the institution. Regarding geographical dispersion, there were 54 HEIs established in more than one campus and 34 that have only one campus. The mean for the sample was eight campuses. Also, most of the sample ( $82 \%$ ) carries out its activities in one federal state and only one HEI has activities in all 24 federal states in Brazil.

\section{Analyzes of reciprocity in the relationships}

The second phase of the analysis verifies reciprocity in the relationships between the HEIs and their relevant stakeholders. In the research instrument, questions were asked about the managers' perceptions of the importance of each stakeholder to the value creation for the HEI, as well the value created for each stakeholder group in their relationship with the HEI (as shown in Table 2).

\begin{tabular}{lccc}
\hline Administrative category & Number & $(\%)$ & \\
\hline School (private institution) & 49 & 55.7 & \\
Public University & 24 & 27.3 & \\
University center & 11 & 12.5 & Table 3. \\
Federal institution & 4 & 4.5 & HEIs in the sample \\
Total & 88 & 100 & \\
\hline
\end{tabular}

Stakeholder theory approach 
BL

33,4

306

Table 4 presents the means for the directors' responses regarding the value each stakeholder group generates for the institution, and the statistical test of means ( $t$-test) paired for independent samples. The responses range from 0 to 10 per stakeholder group within the same variable.

Table 5 presents the information on the perceived value generated for each stakeholder group derived from their relationship with the HEIs.

Tables 4 and 5 present the averages of the responses of the 88 managers and the values of the statistical tests. According to Table 5, the faculty and students are the groups that generate the most value for the HEIs derived from their relationships with the institutions. Next, with a statistical difference compared to the first two groups, is the technicaladministrative body. Last in the table are the suppliers, with a statistically different average value from all the stakeholders listed. These findings are in line with previous studies that considered internal stakeholders as the most salient groups (Mainardes et al., 2012; Cho, 2017). In comparison with other stakeholders, these groups value organizational identity the most and have a higher impact on HEIs (Cho, 2017).

According to Table 5, the perceptions regarding the value created for each stakeholder group in their relationship with the HEIs behave similarly to in the previous question; that is the students and faculty are the groups that receive the most value from their relationship with the institutions. The other groups follow in the same order. These results suggest that there is reciprocity in the relationships between the HEIs and their core stakeholders, which is in line with the theoretical arguments of stakeholder theorists (Freeman et al., 2010; Harrison et al., 2010; Harrison and Bosse, 2013).

Table 4.

Value generated for the HEIs

\begin{tabular}{lcccccccccc}
\hline Stakeholder group & Means & Stu & Fac & TA & Mai & LM & Gov & Alu & Com & Sup \\
\hline Students & 9.44 & - & 0.25 & 0.00 & 0.01 & 0.00 & 0.00 & 0.00 & 0.00 & 0.00 \\
Faculty & 9.39 & 0.25 & - & 0.00 & 0.01 & 0.00 & 0.00 & 0.00 & 0.00 & 0.00 \\
Technical-adm & 9.01 & 0.00 & 0.00 & - & 0.21 & 0.06 & 0.00 & 0.00 & 0.00 & 0.00 \\
Maintainer & 8.64 & 0.01 & 0.01 & 0.21 & - & 0.84 & 0.28 & 0.17 & 0.11 & 0.00 \\
Labor market & 8.58 & 0.00 & 0.00 & 0.06 & 0.84 & - & 0.12 & 0.01 & 0.01 & 0.00 \\
Government & 8.28 & 0.00 & 0.00 & 0.00 & 0.28 & 0.12 & - & 0.57 & 0.32 & 0.00 \\
Alumni & 8.15 & 0.00 & 0.00 & 0.00 & 0.17 & 0.01 & 0.57 & - & 0.73 & 0.00 \\
Community & 8.07 & 0.00 & 0.00 & 0.00 & 0.11 & 0.01 & 0.32 & 0.73 & - & 0.00 \\
Suppliers & 6.64 & 0.00 & 0.00 & 0.00 & 0.00 & 0.00 & 0.00 & 0.00 & 0.00 & - \\
\hline
\end{tabular}

Table 5.

Value generated for the stakeholder

\begin{tabular}{lcccccccccc}
\hline Stakeholder group & Means & Stu & Fac & TA & Mai & LM & Gov & Alu & Com & Sup \\
\hline Students & 9.20 & - & 0.69 & 0.00 & 0.00 & 0.00 & 0.00 & 0.00 & 0.00 & 0.00 \\
Faculty & 9.18 & 0.69 & - & 0.00 & 0.00 & 0.00 & 0.00 & 0.00 & 0.00 & 0.00 \\
Technical-adm staff & 8.72 & 0.00 & 0.00 & - & 0.19 & 0.01 & 0.00 & 0.00 & 0.00 & 0.00 \\
Maintainer & 8.33 & 0.00 & 0.00 & 0.19 & - & 0.38 & 0.24 & 0.04 & 0.05 & 0.00 \\
Labor market & 8.08 & 0.00 & 0.00 & 0.01 & 0.38 & - & 0.46 & 0.03 & 0.06 & 0.00 \\
Government & 7.93 & 0.00 & 0.00 & 0.00 & 0.24 & 0.46 & - & 0.21 & 0.29 & 0.00 \\
Alumni & 7.65 & 0.00 & 0.00 & 0.00 & 0.04 & 0.03 & 0.21 & - & 0.80 & 0.00 \\
Community & 7.58 & 0.00 & 0.00 & 0.00 & 0.05 & 0.06 & 0.29 & 0.80 & - & 0.02 \\
Suppliers & 6.72 & 0.00 & 0.00 & 0.00 & 0.00 & 0.00 & 0.00 & 0.00 & 0.02 & - \\
\hline
\end{tabular}




\section{Correlation analysis}

The third phase of the results analysis involved correlation tests. Tables 6-9 show the Spearman's coefficients for each stakeholder group, revealing the correlations between the four proposed principles of stakeholder theory and value creation $(H 1, H 2, H 3$ and $H 4)$.

According to Table 6, all stakeholder groups show a positive and significant correlation with value creation. These results show that all groups create more value for the institution when they exchange information with the HEI, according to the answers of the heads of the institutions. Thus, there is evidence that confirms H1: The exchange of information about the demands and preferences of stakeholder groups creates more value for the organization.

According to Table 7, active participation by all stakeholder groups except for the government and students in the decision-making process has a positive and significant correlation with value creation for the organization. In other words, all groups, except for the government and students, create more value for the institution if they are included in the decision-making process of the HEI, according to the perceptions of the heads of the institutions. As seven of the nine groups presented positive and significant correlations, there is evidence that confirms H2: The active participation of stakeholder groups in the decision-making process creates more value for the organization.

According to Table 8, relationships of mutual trust with all stakeholder groups show a positive and significant correlation with value creation. In other words, all groups of stakeholders create more value for the institution when there is a relationship based on mutual trust between them and the HEI. Thus, it is possible to confirm H3: A relationship of mutual trust with stakeholder groups creates more value for the organization.

\begin{tabular}{llr}
\hline \multicolumn{2}{c}{ Exchange of information vs value creation } & sig. \\
\hline Maintainer & 0.653 & 0 \\
Community & 0.643 & 0 \\
Suppliers & 0.614 & 0 \\
Alumni & 0.576 & 0 \\
Labor market & 0.537 & 0 \\
Technical-administrative staff & 0.514 & 0 \\
Faculty & 0.411 & 0 \\
Students & 0.382 & 0.001 \\
Government & 0.274 & 0.017
\end{tabular}

Stakeholder theory approach

307

\begin{tabular}{|c|c|c|c|}
\hline \multicolumn{2}{|c|}{ Active participation in decision-making vs value creation } & \multirow{2}{*}{$\frac{\text { sig. }}{0}$} & \\
\hline Maintainer & 0.586 & & \\
\hline Technical-administrative staff & 0.433 & 0 & \\
\hline Community & 0.405 & 0 & \\
\hline Alumni & 0.296 & 0.01 & I able 7. \\
\hline Faculty & 0.255 & 0.028 & Correlation between \\
\hline Labor market & 0.253 & 0.028 & groups' active \\
\hline Suppliers & 0.226 & 0.051 & participation in \\
\hline Government & 0.161 & 0.168 & decision-making and \\
\hline Students & 0.1 & 0.393 & value creation $(H 2)$ \\
\hline
\end{tabular}


BL 33,4

\section{8}

Table 8.

Correlation between the relationship of mutual trust with stakeholders and value creation $(H 3)$
According to Table 9, the relevance of all stakeholders' groups in strategic planning, except students, shows a positive and significant correlation with value creation. These results show that all groups, except students, create more value for the institution when they are considered as relevant in the strategic planning process, according to the answers of the heads of the institutions. Also, as most of the stakeholder groups analyzed showed a positive and significant correlation, there is evidence that confirms H4: Considering stakeholder groups as relevant in the process of organizational strategic planning creates more value for the organization.

\section{Discussion}

The findings of this research showed that relationships based on the principles of stakeholder management can create more value for both the organization and its stakeholders. Based on managing for stakeholder's framework (Freeman et al., 2007), this paper discusses the treatment that HEIs give to their stakeholders, which may lead to the achievement of competitive advantage. The results showed that the exchange of information with all stakeholder groups created more value. This may occur as sharing information improves access to knowledge regarding stakeholders' utility functions. The utility function is defined as the value that the stakeholder receives and that actually has merit for the stakeholder (Harrison and Wicks, 2013). Access to stakeholders' utility functions may generate potential advantages through increased demand and efficiency, innovation and the ability to deal with unexpected situations (Bosse and Coughlan, 2016).

Efforts to encourage the active participation of stakeholders in the decision-making processes of organizations can serve a double purpose. First, participation allows organizations to better include stakeholders' demands and values. In this case, having the

\begin{tabular}{lll}
\hline \multicolumn{2}{c}{ Relationship of mutual trust vs value creation } & sig. \\
\hline Faculty & 0.371 & 0.001 \\
Students & 0.252 & 0.029 \\
Technical-administrative staff & 0.387 & 0.001 \\
Maintainer & 0.786 & 0 \\
Government & 0.3 & 0.009 \\
Labor market & 0.544 & 0 \\
Community & 0.637 & 0 \\
Suppliers & 0.528 & 0 \\
Alumni & 0.471 & 0 \\
\hline
\end{tabular}

\begin{tabular}{|c|c|c|c|}
\hline & \multicolumn{2}{|c|}{ Relevance in strategic planning vs value creation } & sig. \\
\hline & Suppliers & 0.608 & 0 \\
\hline & Maintainer & 0.552 & 0 \\
\hline & Community & 0.55 & 0 \\
\hline \multirow{6}{*}{$\begin{array}{l}\text { Table } 9 \text {. } \\
\text { Correlation between } \\
\text { relevance in strategic } \\
\text { planning and value } \\
\text { creation }(H 3)\end{array}$} & Technical-administrative staff & 0.48 & 0 \\
\hline & Alumni & 0.463 & 0 \\
\hline & Government & 0.394 & 0 \\
\hline & Labor market & 0.324 & 0.005 \\
\hline & Faculty & 0.305 & 0.008 \\
\hline & Students & 0.17 & 0.144 \\
\hline
\end{tabular}


involvement of internal stakeholders such as the maintainer, the technical-administrative staff, and the faculty in the decision-making process facilitates the construction of a more assertive and non-conflicting decision, compared to decisions made exclusively by managers. Second, the involvement of stakeholders in decision-making processes can be used to assess the level of alignment between their interests and the objectives of the organization. In the higher education context, it is vital to guide stakeholders in accordance with strategic organizational objectives, as core institutional values need to be maintained (Mainardes et al., 2012).

Regarding relationships of mutual trust between the institutions and their stakeholders, the results confirmed a positive and significant relationship with value creation for all groups. A relationship of trust with stakeholders can lead to less conflicting situations and help to design strategies that engage stakeholders in organizational activities, a point already highlighted by Ferrero-Ferrero et al. (2018) as being crucial for the legitimacy of HEIs in society. This involvement is important, as processes for identifying and evaluating the participation of stakeholders in the institution's activities may generate organizational change that leads to new opportunities and prevent economic losses.

Regarding relevance in the strategic planning and value creation, the results showed a positive and significant relationship for all groups of stakeholders, except students. This result shows that the relationship with students differs from relationships with other stakeholders. The very existence of universities depends on students, making it crucial to implement specific processes and practices to manage this relationship such as satisfaction surveys (Mainardes et al., 2012). Although students, along with the faculty, are considered the most prominent stakeholders in the higher education context (Chapleo and Simms, 2010; Cho, 2017; Khan and Bhatti, 2016;), this finding may reveal that current students are not considered as being well prepared to participate in decision-making processes.

Previous studies in the literature are generally based on results captured among limited groups of stakeholders - mainly students and faculty - and address very specific issues such as the participation and involvement of stakeholders in sustainability practices and reformulation of the values, mission and vision of HEIs (Turan et al., 2016). The present study considers a more complex and comprehensive overview of HEIs by analyzing both internal and external stakeholders. When all relevant stakeholders are involved in the planning and decision processes of HEIs, the creation of value can be perceived to a greater extent and depth (Hayter and Cahoy, 2018). The relevance of these results is even greater when considering the purpose and social responsibility of HEIs to society. In this context, HEIs face the challenge of implementing innovative practices and policies to better satisfy social demands and to create more value for their stakeholders, including engagement and communication with the various stakeholders and their potential impact on organizational outcomes.

\section{Conclusions and recommendations}

HEIs have increasingly been influenced by a competitive logic based on the creation of sustainable competitive advantages, which involves attracting and retaining more talented faculty and students, developing better research and teaching structures and improving the organizational image. The principles related to stakeholder theory proposed in this research, more specifically:

- Exchange of knowledge;

- A relationship of mutual trust;

- Stakeholder involvement in the decision-making process; and 
BL

33,4

- The inclusion of stakeholder interests in the strategic planning process showed correlations with perceptions of value creation for both internal and external stakeholders.

The present research has shown that theoretical arguments of stakeholder theory also have empirical support in the higher education context.

The main contribution of this study was to empirically show that fairness and reciprocity in stakeholder relationships have the potential to create value for organizations in the higher education context, which, in turn, can represent a source of competitive advantage. The paper highlights different implications for internal and external stakeholders. Internal stakeholders such as students and faculty, present a more direct relationship with HEIs, as their activities are more connected to the purpose of the institution. External stakeholders such as suppliers and the labor market, present a very diverse and complex set of needs, including divergent and competitive ones in some situations. HEIs, however, directly and indirectly, influence both types of stakeholders, including the communities in which they operate, represented by local entities, student associations, religious institutions and others.

\section{Limitations and future studies}

Despite its contributions, this research has some limitations that should be noted. The sample of this study represents a group of directors of HEIs in Brazil and captures their perceptions based on their knowledge and experiences. Thus, the results cannot be generalized to other educational contexts. However, the heterogeneity of the respondents and the degree of importance of their positions in these institutions, mostly as directors and deans, should be highlighted as a relevant way to capture organizational values and strategies, including ones related to stakeholder management.

The results of this study seek to improve and foster future research on the relationship with stakeholders in the context of HEIs. In addition, other empirical studies in different contexts are equally necessary, as well as using other aspects of the stakeholder theory approach not discussed here such as value distribution, synergy among stakeholders' interests and conflicting orientations between groups. Future research could also evaluate the externalities of institutions and their impact on stakeholder relationships and assess possible differences in the strategic purpose of HEIs, which may act as a relevant mediator variable, potentially affecting the relevance of contributions among stakeholders.

\section{Management implications}

This work has also important managerial and strategic implications. Companies that can better identify and serve their relevant stakeholders can gain a competitive advantage and achieve sustainable performance. Based on the results, it is evident that the involvement of stakeholders in organizational processes and practices brings shared benefits. Exchanging information and engaging in collaborative actions leads the company to better align its organizational goals with the social demands of stakeholders.

As already highlighted in previous studies developed in the context of higher education (Cho, 2017; Ferrero-Ferrero et al., 2018), the engagement of stakeholders needs to be explored so that participation and feedback in organizational activities are long-lasting and permanent and so that this relationship is constantly monitored. This study reinforces the importance of implementing strategic practices that formally promote and institutionalize managing for stakeholders in HEIs. 
This paper highlights the importance of developing best practices, processes and strategies related to stakeholders' relationships with these educational institutions, which are important for the development of society. Analyzing and predicting better conditions for fair and reliable relationships between educational institutions and their stakeholders lead to reflections on the role of businesses' engagement with society and their purpose in the community, which is to create more value for all stakeholders.

\section{References}

Bilodeau, L., Podger, J. and Abd-El-Aziz, A. (2014), "Advancing campus and community sustainability: strategic alliances in action”, International Journal of Sustainability in Higher Education, Vol. 15 No. 2, pp. 157-168.

Boaventura, J.M.G., Bosse, D.A., de Mascena, K.M.C. and Sarturi, G. (2020), "Value distribution to stakeholders: the influence of stakeholder power and strategic importance in public firms", Long Range Planning, Vol. 53 No. 2, pp. 1-18.

Bosse, D.A. and Coughlan, R. (2016), "Stakeholder relationship bonds", Journal of Management Studies, Vol. 53 No. 7, pp. 1197-1222.

Bosse, D.A., Phillips, R.A. and Harrison, J.S. (2009), "Stakeholders, reciprocity, and firm performance", Strategic Management Journal, Vol. 30 No. 4, pp. 447-456.

Bridoux, F.M. and Vishwanathan, P. (2020), "When do powerful stakeholders give managers the latitude to balance all stakeholders' interests?”, Business and Society, Vol. 59 No. 2, pp. 232-262.

Chakhar, S. and Saad, I. (2014), "Incorporating stakeholders' knowledge in group decision-making", Journal of Decision Systems, Vol. 23 No. 1, pp. 113-126.

Chapleo, C. and Simms, C. (2010), "Stakeholder analysis in higher education: a case study of the University of Portsmouth", Perspectives, Vol. 14 No. 1, pp. 12-20.

Child, J., Elbanna, S.A.I.D. and Rodrigues, S. (2010), "The political aspects of strategic decision making", in Nutt, P.C. and Wilson D. (Ed.), The Handbook of Decision Making, Wiley, Chichester, pp. 105-137.

Cho, Y.H. (2017), "Towards an engaged campus: measuring and comparing definitive stakeholders' perceptions of university social engagement in South Korea", International Journal of Sustainability in Higher Education, Vol. 18 No. 2, pp. 185-202.

Crane, B. (2020), "Revisiting who, when, and why stakeholders matter: trust and stakeholder connectedness", Business and Society, Vol. 59 No. 2, pp. 263-286.

Esterhuyse, L. (2019), "Towards corporate transparency: the link between inclusion in a socially responsible investment index and investor relations practices", The Bottom Line, Vol. 32 No. 4, pp. 290-307.

Ferrero-Ferrero, I., Fernández-Izquierdo, M.Á., Muñoz-Torres, M.J. and Bellés-Colomer, L. (2018), "Stakeholder engagement in sustainability reporting in higher education: an analysis of key internal stakeholders' expectations", International Journal of Sustainability in Higher Education, Vol. 19 No. 2, pp. 313-336.

Field, A. (2013), Discovering Statistics Using IBM SPSS Statistics, Sage, Sussex.

Freeman, R.E. (1984), Strategic Management: A Stakeholder Approach, Pitman, Boston.

Freeman, R.E., Harrison, J.S. and Wicks, A.C. (2007), Managing for Stakeholders: Survival, Reputation, and Success, Yale University Press London.

Freeman, R.E., Phillips, R. and Sisodia, R. (2020), "Tensions in stakeholder theory”, Business and Society, Vol. 59 No. 2, pp. 213-231.

Freeman, R.E., Harrison, J.S., Wicks, A.C., Parmar, B.L. and De Colle, S. (2010), Stakeholder Theory: The State of the Art, Cambridge University Press Cambridge.

Stakeholder theory approach 
BL 33,4

Friedman, A.L. and Miles, S. (2006, Stakeholders: Theory and practice, Oxford University Press on Demand.

Garcia-Castro, R. and Aguilera, R.V. (2015), "Incremental value creation and appropriation in a world with multiple stakeholders", Strategic Management Journal, Vol. 36 No. 1, pp. 137-147.

Greenwood, M. and Van Buren III, H.J. (2010), "Trust and stakeholder theory: Trustworthiness in the organisation-stakeholder relationship", Journal of Business Ethics, Vol. 95 No. 3, pp. 425-438.

Harrison, J.S. and Bosse, D.A. (2013), "How much is too much? The limits to the generous treatment of stakeholders", Business Horizons, Vol. 56 No. 3, pp. 313-322.

Harrison, J.S. and Wicks, A.C. (2013), "Stakeholder theory, value, and firm performance", Business Ethics Quarterly, Vol. 23 No. 1, pp. 97-124.

Harrison, J.S., Bosse, D.A. and Phillips, R.A.A. (2010), "Managing for stakeholders, stakeholder utility functions, and competitive advantage", Strategic Management Journal, Vol. 31 No. 1, pp. 58-74.

Hayter, C.S. and Cahoy, D.R. (2018), "Toward a strategic view of higher education social responsibilities: a dynamic capabilities approach", Strategic Organization, Vol. 16 No. 1, pp. 12-34.

Hosmer, L.T. (1995), "Trust: the connecting link between organizational theory and philosophical ethics", Academy of Management Review, Vol. 20 No. 2, pp. 379-403.

INEP - National Institute of Educational Studies (2017), "Resumo Técnico - Censo da educação superior 2017", available at: http://download.inep.gov.br/educacao_superior/censo_superior/documentos/ 2018/press-kit_censo_educacao_superior2017.pdf

INEP - National Institute of Educational Studies (2018), "Instrumento de avaliação institucional", available at: http://inep.gov.br/instrumentos1

Jones, T.M., Harrison, J.S. and Felps, W. (2018), "How applying instrumental stakeholder theory can provide sustainable competitive advantage", Academy of Management Review, Vol. 43 No. 3.

Jongbloed, B., Enders, J. and Salerno, C. (2008), "Higher education and its communities: interconnections, interdependencies and a research agenda", Higher Education, Vol. 56 No. 3, pp. 303-323.

Kettunen, J. (2015), "Stakeholder relationships in higher education", Tertiary Education and Management, Vol. 21 No. 1, pp. 56-65.

Khan, G. and Bhatti, R. (2016), "The impact of higher education commission of Pakistan's funding on the collection development budgets of university libraries", The Bottom Line, Vol. 29 No. 1, pp. 12-24.

Kolding, M., Sundblad, M., Alexa, J., Stone, M., Aravopoulou, E. and Evans, G. (2018), "Information management - a skills gap?", The Bottom Line, Vol. 31 Nos 3/4, pp. 170-190.

Li, M. and Nguyen, B. (2017), "When will firms share information and collaborate to achieve innovation? A review of collaboration strategies", The Bottom Line, Vol. 30 No. 1, pp. 65-86.

Lourenço, R. and Mano, M. (2017), "The role of general councils in the supervision of the organizational performance of higher education institutions", ICHEM 2017: 19th International Conference on Higher Education and Management.

MacDonald, A., Clarke, A. and Huang, L. (2019), "Multi-stakeholder partnerships for sustainability: designing decision-making processes for partnership capacity", Journal of Business Ethics, Vol. 160 No. 2, pp. 409-426.

Mainardes, E.W., Alves, H. and Raposo, M. (2010), “An exploratory research on the stakeholders of a university”, Journal of Management and Strategy, Vol. 1 No. 1, pp. 76-88.

Mainardes, E.W., Alves, H. and Raposo, M. (2012), "A model for stakeholder classification and stakeholder relationships”, Management Decision, Vol. 50 No. 10, pp. 1861-1879.

Ngah, R. and Wong, K. (2020), "Linking knowledge management to competitive strategies of knowledge-based SMEs", The Bottom Line, Vol. 33 No. 1, pp. 42-59.

Parnell, B., Stone, M. and Aravopoulou, E. (2018), "How leaders manage their business models using information", The Bottom Line, Vol. 31 No. 2, pp. 150-167. 
Phillips, R.A. (1997), "Stakeholder theory and a principle of fairness", Business Ethics Quarterly, Vol. 7 No. 1, pp. 51-66.

Pirson, M., Martin, K. and Parmar, B. (2017), "Formation of stakeholder trust in business and the role of personal values", Journal of Business Ethics, Vol. 145 No. 1, pp. 1-20.

Schneider, T. and Sachs, S. (2017), "The impact of stakeholder identities on value creation in issuebased stakeholder networks", Journal of Business Ethics, Vol. 144 No. 1, pp. 41-57.

Stocker, F., Arruda, M.P., Mascena, K.M.C. and Boaventura, J.M.G. (2020), "Stakeholder engagement in sustainability reporting: a classification model", Corporate Social Responsibility Environmental Management, Vol. 1, pp. 1-10.

Stone, M., Aravopoulou, E., Evans, G., Aldhaen, E. and Parnell, B. (2019), "From information mismanagement to misinformation - the dark side of information management", The Bottom Line, Vol. 32 No. 1, pp. 47-70.

Stone, M., Aravopoulou, E., Gerardi, G., Todeva, E., Weinzierl, L., Laughlin, P. and Stott, R. (2017), "How platforms are transforming customer information management", The Bottom Line, Vol. 30 No. 3, pp. 216-235.

Stoner, J.A.F. and Freeman, R.E. (1999), Administração, LTC São Paulo.

Sulkowski, A.J., Edwards, M. and Freeman, R.E. (2018), "Shake your stakeholder: firms leading engagement to cocreate sustainable value", Organization and Environment, Vol. 31 No. 3, pp. 223-241.

Tantalo, C. and Priem, R.L. (2016), "Value creation through stakeholder synergy", Strategic Management Journal, Vol. 37 No. 2, pp. 314-329.

Turan, F.K., Cetinkaya, S. and Ustun, C. (2016), "A methodological framework to analyze stakeholder preferences and propose strategic pathways for a sustainable university", Higher Education, Vol. 72 No. 6, pp. 743-760.

\section{Further reading}

Freeman, R.E., Kujala, J., Sachs, S. and Stutz, C. (2017), "Stakeholder engagement: practicing the ideas of stakeholder theory", in Freeman, R.E., Kujala, J. and Sachs, S. (Ed.), Stakeholder Engagement: Clinical Research Cases, Springer, Cham. pp. 1-12.

\section{Corresponding author}

Fabricio Stocker can be contacted at: fabriciostocker@usp.br
Stakeholder theory approach 